\title{
Comparison of mRNA for IGFs and their binding proteins in the oviduct during the peri-oestrous period between dairy heifers and lactating cows
}

\author{
Theerawat Swangchan-Uthai ${ }^{1,3}$, Siobhan W Walsh ${ }^{2}$, Sarah L H Alexander ${ }^{1}$, Zhangrui Cheng ${ }^{1}$, \\ Mark A Crowe ${ }^{2}$, Alexander C O Evans ${ }^{2}$ and D Claire Wathes ${ }^{1}$ \\ ${ }^{1}$ Reproduction Group, Department of Veterinary Basic Sciences, Royal Veterinary College, Hawkshead Lane, North \\ Mymms, Hatfield, Hertfordshire, AL9 7TA, UK, ${ }^{2}$ School of Agriculture, Food Science and Veterinary Medicine, \\ University College Dublin, Dublin, Ireland and ${ }^{3}$ Department of Obstetrics, Gynaecology and Reproduction, Faculty of \\ Veterinary Science, Chulalongkorn University, Bangkok 10330, Thailand
}

Correspondence should be addressed to D C Wathes; Email: dcwathes@rvc.ac.uk

\begin{abstract}
The oviduct provides the environment to support gamete maturation, fertilisation and early embryo development. As there is a high incidence of early embryonic death in lactating dairy cows, this study compared expression of IGF family members in the oviduct between lactating Holstein-Friesian dairy cows $(n=16,81 \pm 2.4$ days in milk) and nulliparous heifers $(n=16$, age $1.6 \pm 0.07$ years $)$ at three stages of the oestrous cycle: A) newly selected dominant follicle in the luteal phase, B) follicular phase before the LH surge and C) pre-ovulatory phase after the LH surge. Expression of IGF1, IGF2, IGF binding protein 2 (IGFBP2), IGFBP3 and IGFBP6 mRNA was determined in the ampulla of the oviduct. Oviduct side (ipsilateral or contralateral) with respect to the dominant follicle did not affect gene expression. Expression of IGF1 and all three IGFBPs increased significantly between the luteal and the pre-ovulatory phases, with no further significant alteration post-LH surge. Concentrations of circulating IGF1 were higher in heifers than in cows, as was the mRNA expression of IGF1, IGFBP3 and IGFBP6. The pre-LH surge rise in IGFBP2 mRNA was only observed in heifers. IGF2 expression was not influenced by either age or stage of cycle. These three IGFBPs are generally considered to inhibit IGF action. These results indicate tight regulation of IGF bioavailability in the oviductal environment around oestrus, with pronounced differences between cows and heifers, which are likely to influence early embryonic development. Further studies are required to assess the implications for embryo survival. Reproduction (2011) 142 457-465
\end{abstract}

\section{Introduction}

Genetic selection of dairy cows for high milk yields has been associated with a reduction in fertility (Veerkamp et al. 2001). Less than $40 \%$ of inseminations typically result in the birth of a live off spring (Lucy 2001, Santos et al. 2004). Early embryonic mortality is a major cause of loss, estimated at about $40 \%$ in the first 2 weeks after insemination (Robinson et al. 2008). In high-producing dairy cows, there is evidence that a higher proportion of these losses occur before day 8 after insemination (Diskin \& Morris 2008). A number of factors may contribute to this high loss rate including poor oocyte quality (Leroy et al. 2008), inadequate follicular and luteal steroidogenesis (Robinson et al. 2008) and an unfavourable environment within the reproductive tract (Wathes et al. 2007a). Fertility is typically somewhat higher in dairy heifers than in mature cows, with first service conception rates of $57 \%$ in US Holstein heifers (Kuhn et al. 2006) and 67\% in British Holstein-Friesian heifers (Brickell et al. 2009). This suggests that a concurrent lactation has a greater negative impact on conception in modern dairy cows than the altered genotype associated with selection for a high yield.

Within the bovine oviduct, the ampulla supports final oocyte maturation, fertilisation, cleavage and development to an 8-16 cell embryo, while the isthmus functions as a sperm reservoir and promotes capacitation (Hunter 1988, Ellington 1991, Buhi 2002, RodriguezMartinez 2007). The luminal epithelium contains both ciliated cells and nonciliated, secretory cells, which are responsible for oviduct fluid formation (Yaniz et al. 2000). The morphology and activity of the epithelium change during the oestrous cycle (Yaniz et al. 2000). Secretory activity increases during the peri-ovulatory period and early luteal phase under the influence of oestrogen (Murray 1995, Buhi et al. 2000) but decreases during the luteal phase and pregnancy when there is a prevailing high-progesterone concentration (Nayak et al. 1976). Oviductal fluid can enhance sperm survival 
(Boilard et al. 2004) and fertilisation and provides an environment rich in 'embryotrophic factors' capable of enhancing embryo development (Leese 1988, Lai et al. 1996).

The extended insulin-like growth factor (IGF) superfamily includes two ligands (IGF1 and IGF2), two receptors (IGF1R and IGF2R) and at least six binding proteins (IGFBPs; Clemmons 1997). The biologic responses of both IGF1 and IGF2 are mediated predominantly by IGF1R (LeRoith et al. 1995), resulting in actions such as differentiation, mitogenesis and inhibition of apoptosis (Ullrich et al. 1986, Jones \& Clemmons 1995). IGF signalling is influenced by competitive binding to the IGFBPs, which can either inhibit or potentiate IGF activities and thus provide differential regulation of the IGF system between different tissues (Clemmons 1997). Many components of the IGF system are nutritionally regulated (Thissen et al. 1994). Dairy cows in early lactation are exposed to a period of negative energy balance (NEB), which may last for up to 20 weeks in high yielding animals (Wathes et al. 2007a). During this time, there is altered expression of IGF family members in the liver (Lucy et al. 2001, Fenwick et al. 2008a), ovary (Llewellyn et al. 2007), oviduct (Fenwick et al. 2008b) and uterus (Wathes et al. 2009a). Together, these changes associated with NEB are not only responsible for a marked peripartum decline in circulating IGF1 concentrations (Butler 2003, Taylor et al. 2004) but are also thought to influence the half-life of IGFs in the circulation and the bioavailability of IGF within reproductive tissues. Measurements of circulating IGF1 have, therefore, been used as indicators of metabolic status, which are associated with fertility (Velazquez et al. 2008). For example, the interval to first ovulation after calving is shorter in cows with higher IGF1 concentrations (Butler 2003, Patton et al. 2007), and multiparous cows with lower IGF1 concentrations both before and immediately after calving experience longer calving to conception intervals and are less likely to conceive (Taylor et al. 2004, Wathes et al. 2007 b).

Previous studies in various species have shown that expression of the IGF system in the oviduct alters according to stage of the oestrous cycle. For example, local production of IGF1 mRNA increases during oestrus and the early luteal phase in pigs (Simmen et al. 1990), sheep (Stevenson \& Wathes 1996) and cows (Schmidt et al. 1994, Pushpakumara et al. 2002). The majority of studies did not detect IGF1 mRNA in pre-implantation bovine embryos (Yaseen et al. 2001, Moore et al. 2007, Warzych et al. 2007, Wang et al. 2009). IGF2 mRNA was, however, present in bovine pre-implantation embryos as well as IGF2 protein in cumulus cells, oocytes and two-cell stage embryos (Watson et al. 1999, Wang et al. 2009). IGF1R mRNA is expressed in both the muscle and the mucosa of the oviduct (Pushpakumara et al. 2002, Fenwick et al. 2008b), in spermatozoa (Henricks et al. 1998) and in oocytes and embryos at all stages of development (Watson et al. 1999, Wang et al. 2009). Together, these data suggest that locally produced and/or systemically derived IGFs may influence the gametes and embryo indirectly through local effects on oviductal secretory activity or directly after release into the lumen (Wathes et al. 1998, Watson et al. 1999). A key role for the IGFs at this time is supported by in vitro studies demonstrating that both IGF1 and IGF2 can stimulate the development of fertilised bovine embryos to the morula and blastocyst stages (Matsui et al. 1997, Palma et al. 1997, Watson et al. 1999, Wang et al. 2009, Neira et al. 2010). IGF2 may also promote proliferation and metabolic activity of the oviduct (Tiemann \& Hansen 1995).

The aim of this study was to investigate the hypothesis that the IGF system in the bovine oviduct is affected not only by time relative to ovulation but also by lactation. The study measured mRNA expression of IGF1 and IGF2 and three IGFBPs (IGFBP2, IGFBP3 and IGFBP6) at three stages leading up to ovulation in heifers and lactating cows. These binding proteins were selected as we have shown previously that they are: a) expressed in bovine oviduct and b) differentially regulated in the reproductive tract according to energy balance status (Pushpakumara et al. 2002, Fenwick et al. 2008b).

\section{Results}

Results are reported for lactating cows (two to seven lactations, age $5.7 \pm 0.5$ years, $81 \pm 2.4$ days in milk; mean \pm s.E.M., $n=16$ ) and heifers (mean age of $1.6 \pm 0.07$ years; $n=16$ ). All animals were synchronised so that samples of ampulla from both the ipsilateral and the contralateral sides with respect to the presence of a dominant follicle could be collected at three stages of the oestrous cycle: A) newly selected dominant follicle on day 14 of the luteal phase, B) pre-ovulatory follicle prior to oestrus and C) luteinising pre-ovulatory follicle, after the LH surge (see Table 1). Stage of the cycle was confirmed by measurement of circulating progesterone concentrations. All animals in group A had elevated values of plasma progesterone of $>6 \mathrm{ng} / \mathrm{ml}$ $(8.1 \pm 0.51 \mathrm{ng} / \mathrm{ml}$, mean \pm s.E.M. $)$, whereas concentrations were $\leq 0.22 \mathrm{ng} / \mathrm{ml}$ for all animals in groups B and C. The mean IGF1 concentration in blood did not change over time but was significantly higher in heifers than in cows ( $467 \pm 34$ and $130 \pm 9 \mathrm{ng} / \mathrm{ml}$ respectively).

Concentrations of IGF1, IGF2, IGFBP2, IGFBP3 and IGFBP6 were measured in all samples as absolute values using reverse transcriptase quantitative PCR (qPCR). In addition, $A C T B$ and $R N 18 S 1$ were included as reference genes. Across all samples, IGF1 mRNA expression was considerably higher than that of IGF2 mRNA $(67 \pm 3.6$ and $2.4 \pm 0.2 \mathrm{fg}$ cDNA/50 ng RT RNA respectively, $n=32$ ). Amongst the IGFBP mRNAs analysed expression of IGFBP6 $>$ IGFBP3 $>$ IGFBP2 $(18 \pm 3.0,7 \pm 1.0$ and $0.9 \pm 0.2 \mathrm{fg}$ cDNA/50 ng RT RNA respectively). 
Table 1 Summary scheme of the synchronisation protocol.

\begin{tabular}{llll}
\hline & $\begin{array}{l}\text { Group A } \\
\text { Day 14 luteal } \\
\text { Five cows + six heifers }\end{array}$ & $\begin{array}{l}\text { Group B } \\
\text { Pre-LH surge } \\
\text { Seven cows + five heifers }\end{array}$ & $\begin{array}{l}\text { Group C } \\
\text { Post-LH surge } \\
\text { Four cows + five heifers }\end{array}$ \\
\hline Days ${ }^{\mathrm{a}}$ & Insert CIDR & Insert CIDR & Insert CIDR \\
-12 & Remove CIDR & Remove CIDR & Remove CIDR \\
-3 & i.m. PG & i.m. PG & i.m. PG \\
-2 & Check oestrus & Check oestrus & Reck oestrus \\
0 & Reinsert CIDR & Reinsert CIDR & Reinsert CIDR \\
+8 & i.m. PG & i.m. PG \\
+13 & Remove CIDR & & Remove CIDR \\
+14 & Slaughter & Remove CIDR & i.m. GNRH \\
+15 & & Slaughter & Slaughter \\
+16 & & & \\
\hline
\end{tabular}

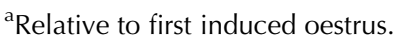

Initial comparison of the gene expression in every animal $(n=32)$ between the ipsilateral and the contralateral ampullae with respect to the dominant follicle using paired $t$-tests showed no significant difference for any of the genes studied ( $P=0.35-0.94$, data not shown).

Mixed model analysis was then used to compare expression patterns of the genes of interest in the oviduct according to 1) stage of the oestrous cycle, 2) lactation status (cow/heifer) and 3 ) the stage $\times$ status interaction. There were no differences in $A C T B$ or $R N 18 S 1$ expression according to stage or status of the animals. There was also no difference in the conclusions reached when values from the IGF-related genes were analysed as either absolute concentrations ( $\mathrm{fg} \mathrm{cDNA} / 50 \mathrm{ng} \mathrm{RT}$ RNA) or relative changes (after normalisation against $A C T B$ or $R N 1851$ ). The original concentration data are, therefore, presented here.

Expression results according to stage of cycle are summarised in Fig. 1. Concentrations of IGF1 $(P<0.004)$ and IGFBP2 $(P<0.017)$ increased from day 14 of the luteal phase to the pre-LH surge and showed a tendency to decrease again after the $\mathrm{LH}$ surge. IGFBP3 $(P<0.017)$ and IGFBP6 $(P<0.016)$ also increased from day 14 of the luteal phase to the pre-LH surge, with no further significant alteration after the LH surge. IGF2 expression remained low at all stages with no change in expression between time points.

Data on the influence of lactation status on expression of IGF family members are summarised in Table 2. Expression of IGF1, IGFBP2, IGFBP3 and IGFBP6 mRNAs was significantly higher in heifers than in cows (fold changes $1.2,1.8,2.1$ and $1.6, P=0.033, P=0.053$, $P=0.003$ and $P=0.041$ respectively). There was no difference in IGF2 mRNA expression according to lactation status.

The only gene to show a significant stage $\times$ lactation status interaction was IGFBP2. For this, the significant increase in expression before the LH surge occurred only in the heifers (Fig. 2).

\section{Discussion}

Fertilisation and early embryo development take place within the ampullary region of the oviduct. The IGF system is an important contributor to this environment. This study compared oviductal expression patterns for IGF family members over the peri-oestrous period and demonstrated that IGF1, IGFBP2, IGFBP3 and IGFBP6 mRNAs increased before the $\mathrm{LH}$ surge with differential expression between non-lactating heifers and lactating cows. In contrast, IGF2 mRNA expression did not alter according to either stage of cycle or age of cow. This study focussed on IGFBPs, based on our previous studies showing their differential expression in the reproductive
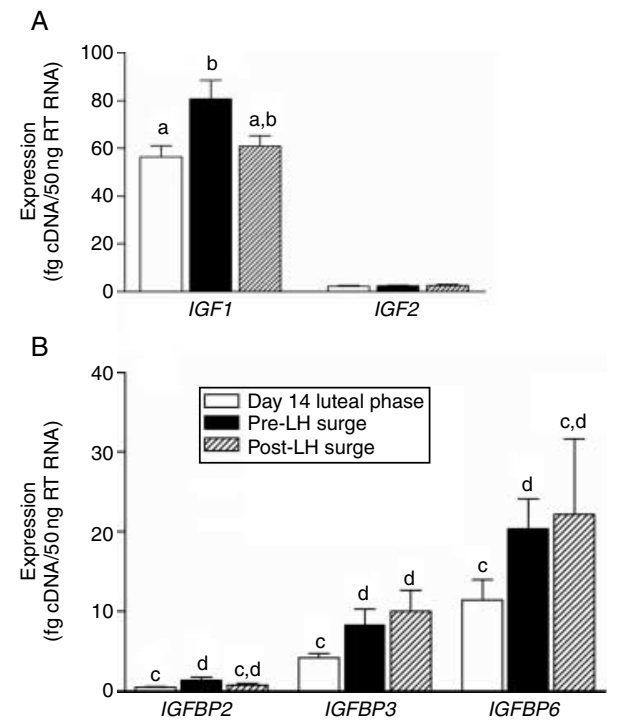

Figure 1 Expression levels of (A) IGF1 and IGF2 mRNA and (B) IGFBP2, IGFBP3 and IGFBP6 mRNA (fg/50 ng RT RNA) in the ampullary region of the oviduct of animals on day 14 of the luteal phase $(n=11)$, pre-LH surge $(n=12)$ and post-LH surge $(n=9)$. Values are mean \pm s.E.M. For each gene shown, values with different superscripts are significantly different between times, $\mathrm{b}>\mathrm{a}, P<0.01, \mathrm{~d}>\mathrm{c} P<0.05$. 
Table 2 Comparison of mRNA expression of IGF family members in the ampullary region of oviducts between cows $(n=16)$ and heifers $(n=16)$ based on mixed model analysis ${ }^{\mathrm{a}}$.

\begin{tabular}{|c|c|c|c|c|}
\hline Gene & Cow $n=16$ & Heifer $n=16$ & $\begin{array}{l}\text { Fold increase } \\
\text { in heifers }\end{array}$ & $\boldsymbol{P}$ \\
\hline IGF1 & $61.6 \pm 5.70$ & $71.1 \pm 5.06$ & $\times 1.2$ & 0.033 \\
\hline IGF2 & $2.4 \pm 0.20$ & $2.3 \pm 0.37$ & No change & 0.154 \\
\hline IGFBP2 & $0.6 \pm 0.09$ & $1.1 \pm 0.30$ & $\times 1.8$ & 0.053 \\
\hline IGFBP3 & $4.6 \pm 0.75$ & $9.8 \pm 1.86$ & $\times 2.1$ & 0.003 \\
\hline IGFBP6 & $13.5+2.35$ & $21.7+5.54$ & $\times 1.6$ & 0.041 \\
\hline$R N 18 S 1^{\mathrm{b}}$ & $\begin{array}{l}1.9 \times 10^{6} \\
\pm 0.38 \times 10^{6}\end{array}$ & $\begin{array}{l}1.5 \times 10^{6} \\
\pm 0.26 \times 10^{6}\end{array}$ & No change & 0.786 \\
\hline$A C T B^{\mathrm{b}}$ & $\begin{array}{l}1.3 \times 10^{4} \\
\pm 0.31 \times 10^{4}\end{array}$ & $\begin{array}{l}1.9 \times 10^{4} \\
\pm 0.38 \times 10^{4}\end{array}$ & No change & 0.350 \\
\hline
\end{tabular}

${ }^{a}$ Values are mean \pm S.E.M. and are expressed as fg cDNA/50 ng RNA.

${ }^{\mathrm{b}}$ Included as reference genes for comparison.

tract according to nutritional status (Fenwick et al. 2008a, 2008b) and between cows and heifers (Pushpakumara et al. 2002). In contrast, expression levels of the $I G F 1 R$ did not differ in these situations and we were previously unable to detect IGF2R in bovine oviduct by qPCR (Fenwick et al. 2008a, 2008b).

In accordance with previous work (Pushpakumara et al. 2002), transcripts for IGF1 mRNA were highest in the pre-ovulatory stage before the $\mathrm{LH}$ surge. In both ovine and bovine ampulla, IGF1 mRNA was localised mainly to stromal fibroblasts underlying the luminal epithelium in the mucosa and to the surrounding smooth muscle cells (Stevenson \& Wathes 1996, Pushpakumara et al. 2002). In contrast, IGF1 protein was localised mainly in the secretory epithelial cells, supporting the likelihood that IGF1 is exported into the oviductal lumen (Schmidt et al. 1994). In the results reported here, expression of IGF1 mRNA was slightly (1.2-fold) higher in heifers than in cows. We similarly found slightly higher mRNA concentrations in cows in mild compared with severe NEB in early lactation. The bovine oviduct has receptors for oestradiol, $\mathrm{GH}$ and glucocorticoids. As their receptor expression was highly correlated with that of IGF1 mRNA (Fenwick et al. 2008b), all three hormones may be involved in regulating local production of IGF1 within the oviduct.

Oviductal expression of IGF2 mRNA was much lower than that of IGF1 mRNA. Xia et al. (1996) similarly reported low IGF2 mRNA expression in bovine oviduct. The lack of difference in IGF2 mRNA expression between any of the treatment groups agrees with our previous work in the cow (Pushpakumara et al. 2002, Fenwick et al. 2008b). Studies using in situ hybridisation showed that IGF2 mRNA was predominantly expressed in the muscle layer (Stevenson \& Wathes 1996, Pushpakumara et al. 2002). Our results, therefore, indicate that IGF2 production within the mucosa of the ampulla is not acutely regulated. In contrast, Watson et al. (1999) reported that bovine oviduct cultures released ten times more IGF2 than IGF1 while Pershing et al. (2002) found increased oviductal IGF2 mRNA expression in the early luteal phase following bST treatment. The potential role of local IGF2 production within the oviduct, therefore, remains uncertain.

This study showed increased expression of IGFBP2, IGFBP3 and IGFBP6 mRNA between the luteal stage of the cycle and the onset of the LH surge when oestrus, and therefore mating or artificial insemination, normally occurs. Furthermore, all three IGFBPs were influenced by the lactational status: the increase in IGFBP2 mRNA was only present in heifers and the rise in both IGFBP3 and IGFBP6 mRNA expression was likewise greater in heifers than in cows. All three of these binding proteins are expressed in the oviductal mucosa, with IGFBP2 and IGFBP3 mRNA also present in the muscle layer (Stevenson \& Wathes 1996, Pushpakumara et al. 2002, Fenwick et al. 2008b). In the bovine uterus, IGFBP2 mRNA was reported to increase in the late luteal phase (Geisert et al. 1991), whereas IGFBP6 mRNA expression in the endometrium of the ewe was highest around ovulation and the early luteal phase (Gadd et al. 2002). In agreement with the findings reported here, IGFBP3 mRNA expression in the oviduct increased at oestrus in the ewe and cow (Stevenson \& Wathes 1996, Pushpakumara et al. 2002).

Expression of all of these IGFBPs is thus influenced by stage of oestrous cycle as well as nutrition (Thissen et al. 1994, Clemmons 1997). We previously reported reduced expression of IGFBP2, IGFBP3 and IGFBP6 mRNAs in the oviduct when cows were in severe compared with mild NEB after calving (Fenwick et al. $2008 b$ ). Hepatic down-regulation of IGFBP3 and IGFBP6 mRNA in cows in severe NEB was associated with the concurrent down-regulation of the $\mathrm{GH}$ receptor (Fenwick et al. 2008a). Hepatic IGFBP3 mRNA expression is regulated concurrently with IGF1 (Woelfle \& Rotwein 2004) and a positive correlation between IGFBP3 and uterine IGF1 mRNA levels has also been reported (Pershing et al. 2002). In contrast, hepatic IGFBP2 mRNA expression was increased by severe NEB (Fenwick et al. 2008a). Together, these data suggest that there is complex regulation of IGFBP expression in the

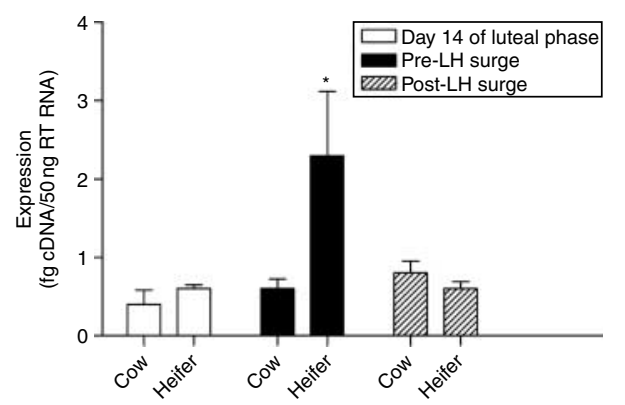

Figure 2 Two-way interaction from mixed model analysis showing the combined influences of animal status (cow/heifer) and stage of the oestrous cycle on expression of IGFBP2 mRNA (fg/50 ng RT RNA). The increase in expression pre-LH surge was only found in the heifers, $* P<0.01$ 
oviduct by both metabolic status and ovarian steroid hormone environment.

The changes in IGFBP expression shown here imply that the oviduct of the heifer is exposed to higher concentrations of IGFBPs around oestrus than the lactating cow. This study has only measured mRNA, and additional regulation of IGFBP activity can occur at the protein level, for example by proteolysis (Christians \& Gruslin 2010). It is not currently known whether any of these binding proteins are secreted into the lumen with the potential then to influence the gametes and embryo directly. However, expression of IGFBP2 to IGFBP5 mRNAs has also been detected in bovine embryos from the one cell to the blastocyst stages (Winger et al. 1997, Watson et al. 1999). The IGFBPs are generally considered to inhibit IGF action, with both IGFBP2 and IGFBP6 having a much higher affinity for IGF2 than IGF1 (Clemmons 1997, Bach 2005), whereas the affinities of IGFBP3 for both IGF1 and IGF2 are similar (Rajaram et al. 1997). The evidence presented here, therefore, suggests that the embryos in the heifers will have reduced signalling from IGFs through the IGF1R due to the likely inhibitory effect of each of the locally produced IGFBPs. Whilst this result might be considered unexpected, it concurs with the quiet embryo hypothesis, as reviewed by Leese et al. (2008). These authors concluded that the energy requirements of the embryo during the early cleavage stages are quite low. Less viable embryos were metabolically more active with a greater production of reactive oxygen species damaging the DNA and triggering a cellular stress response. The higher IGFBP expression may thus be needed to counteract the higher concentrations of circulating IGF1 present in heifers than cows, which peak at around puberty and then decline (Velazquez et al. 2008, Wathes et al. 2009b). This suggestion must be considered speculative until further functional studies can be undertaken. Other aspects may be important for fertility, for example the ratio of IGF and IGFBP proteins in the oviductal lumen. In addition, there are clearly other differences in the reproductive systems of cows and heifers. For example, some metabolite concentrations, in particular fatty acid composition, differed between dominant follicles collected from the animals used in this study (Bender et al. 2010).

The follicular fluid of the pre-ovulatory follicle contains high concentrations of oestradiol, cortisol, IGFs and other metabolites (Yding Andersen 2002, Mihm \& Evans 2008) and these will be released along with the oocyte at ovulation, potentially leading to raised concentrations within the oviduct. The results presented here agree with our previous study in failing to show any differences in expression of IGF family members between the ipsilateral and the contralateral oviducts with respect to the dominant follicle (Fenwick et al. 2008b). A previous study compared gene expression in oviduct epithelial cells obtained from Simmental heifers in the early luteal phase using cDNA array hybridisation.
This approach detected 27 genes that were up-regulated in the ipsilateral oviduct and eight in the contralateral oviduct (Bauersachs et al. 2003). These included cell surface proteins, enzymes and proteins involved in cellcell interaction, signal transduction and immune function but not any members of the IGF family.

In summary, this study provides evidence for the dynamic regulation of the IGF system within the oviduct by both lactational status and the systemic endocrine changes associated with the development of a dominant follicle. The oviduct of a growing heifer around the time of oestrus and the early luteal phase will be exposed to high circulating IGF1 from the circulation, slightly raised local production of IGF1, and raised concentrations of IGFBP2, IGFBP3 and IGFBP6, which are together likely to inhibit both IGF1 and IGF2 bioactivity. In contrast, a lactating cow has much lower circulating IGF1 in association with reduced oviductal IGFBP expression. Although oviductal expression of IGF2 is low, IGF2 production by the early embryo itself may also be affected by locally produced IGFBPs. The differences in IGFBP mRNA expression reported here indicate that there is tight regulation of IGF bioavailability in the oviductal environment. Further studies are required to assess the implications of these differences in IGFBP expression for development and survival of the embryo.

\section{Materials and Methods}

\section{Animals and experimental design}

All experimental procedures were conducted in accordance with the European Community Directive, 86-609-EC. The study compared two groups of Holstein-Friesian cattle. The multiparous cow group ( $n=16$, range $2-7$ lactations) had a mean age of $5.7 \pm 0.50$ years and were $81 \pm 2.4$ days in milk (range 68-108 days) at the start of the study, when daily milk yield was $26.2 \pm 1.6 \mathrm{~kg}$ (mean \pm S.E.M.). The nulliparous heifer group had a mean age of $1.6 \pm 0.07$ years, $n=16$. The animals were studied at time points with respect to time of calving (cows) or age (heifers) when such animals would normally be bred on commercial dairy farms.

Oestrous cycles were pre-synchronised and all animals were allocated to one of three slaughter time groups: A) animals with a newly selected dominant follicle $(n=11)$, B) a differentiated dominant follicle before the LH surge $(n=12)$ and C) a preovulatory dominant follicle after the $\mathrm{LH}(n=9)$. Cows and heifers were selected independently to ensure sufficient distribution between the three groups. Groups A, B and C were achieved using a synchronisation programme summarised in Table 1. All animals were pre-synchronised for 8 days with progesterone via an intra-vaginal device (Eazi-Breed CIDR; Pfizer Pharma GmbH, Karlsruhe, Germany) containing $1.38 \mathrm{~g}$ progesterone. After $24 \mathrm{~h}$ of CIDR removal, animals received an i.m. injection of $500 \mu \mathrm{g}$ of a $\mathrm{PGF}_{2 \alpha}$ analogue cloprostenol (Estrumate; Intervet/Schering-Plough Animal Health, Bray, Co., Wicklow, Ireland). Animals were then fitted with heat mount detectors (Kamar; Kamar, Inc., Steamboat Springs, CO, USA) 
and observed for oestrus every $8 \mathrm{~h}$ between 48 and $72 \mathrm{~h}$ after $\mathrm{PGF}_{2 \alpha}$ administration. Oestrus was confirmed when the animals stood to be mounted by another animal. The day on which standing oestrus first occurred was designated as day 0 in the synchronisation programme. On day 8 of the next cycle, a used CIDR was re-inserted into all animals and ovarian follicle development was monitored daily by ultrasonographic examination (Aloka SSD-900 linear array trans-rectal probe, $7.5-\mathrm{MHz}$ transducer; BCF Ireland Ltd, Fermoy, Ireland). On day 14, the used CIDRs were removed from animals in group A and they were subsequently slaughtered at an abattoir, at which time they presented a clear early dominant follicle whilst being in the mid luteal phase of the cycle. Animals in groups $B$ and $C$ received an i.m. injection of $500 \mu$ g cloprostenol on day 13 , followed by the removal of the CIDR device $48 \mathrm{~h}$ later. The animals in group $\mathrm{B}$ were then slaughtered before the onset of the LH surge, between 24 and $30 \mathrm{~h}$ post-CIDR removal. The animals in group $\mathrm{C}$ were given an i.m. injection of $5 \mathrm{ml} \mathrm{GNRH} \mathrm{(Receptal,} \mathrm{Intervet/}$ Schering-Plough Animal Health, Bray, Co.) $30 \mathrm{~h}$ post-CIDR removal, initiating the $\mathrm{LH}$ surge. Slaughter was carried out $\sim 18-22 \mathrm{~h}$ after the administration of GNRH. Blood samples were obtained from all animals by jugular venipuncture on the day of slaughter for measurement of IGF1 and progesterone. Ovarian characteristics at slaughter were confirmed by measurement of the external diameter of each follicle and assay of oestradiol-17 $\beta$ and progesterone in the follicular fluid as described previously (Bender et al. 2010).

\section{Tissue collection}

Following slaughter, reproductive tracts were collected within 15 min, oviducts were trimmed free of surrounding connective tissue and an $\sim 10 \mathrm{~mm}$ long section of the ampulla from each of the left and right oviducts was dissected and promptly frozen in liquid nitrogen. It was noted at the time of tissue collection which ampulla sample was ipsilateral and which was contralateral to the dominant ovarian follicle present on the ovary of each animal. The samples were then stored at $-80^{\circ} \mathrm{C}$.

\section{Hormone assays}

Plasma concentrations of IGF1 were determined using a RIA following acid-ethanol extraction as previously described (Beltman et al. 2010) using recombinant IGF1 (Upstate, Millipore, Temecula, CA, USA) as the iodination preparation and as standard and $50 \mu \mathrm{l}$ anti-human (h) IGF1, NHPP-NIDDK AFP 4892898 (National Hormone and Peptide Program, Torrance, CA, USA) dilution 1:750 000 as primary antibody. The intra-assay coefficients of variation $(\mathrm{CV}, n=6)$ were 17.8, 13.4 and $18.9 \%$ for low, medium and high IGF1 quality control sera respectively. The inter-assay $\mathrm{CV}(n=5)$ for the same control sera were $12.2,10.1$ and $11.3 \%$ respectively.

Serum progesterone concentrations were determined using the solid phase RIA Coat-A-Count progesterone kit (Siemens Medical Solutions Diagnostics, Los Angeles, CA, USA) as previously described (Forde et al. 2010). All samples were assayed within one assay. The intra-assay CV $(n=4)$ were 6.2, 6.2 and $9 \%$ for low-, medium- and high-quality control serum pools respectively.

\section{RNA isolation, RT and $q P C R$}

The procedures of RNA extraction, RT and qPCR were described in our previous studies (Fenwick et al. 2008a, 2008b, Wathes et al. 2011). Total RNA was extracted from 50 to $100 \mathrm{mg}$ of frozen segments taken from the ampullary region of the oviducts from each cow using TRIzol Reagent (Fisher Scientific UK-Invitrogen) and chloroform and subsequently precipitated using isopropanol with a protocol developed according to ARK Genomics (http://www.ark-genomics.org/ protocols/). RNA concentration and purity of each sample was evaluated using a NanoDrop ND-1000 spectrophotometer (NanoDrop Technologies, Inc., Wilmington, DE, USA), where all samples had an acceptable 260/280 ratio of absorbance between 1.8 and 2.1.

In the following stage, $1 \mu \mathrm{g}$ total RNA was treated for genomic DNA carryover with RNase-free DNase according to the guidelines supplied by the manufacturer (Promega Corporation). Subsequently, the DNase-treated RNA was generated into cDNA in $20 \mu \mathrm{l}$ reactions using random hexamer primers, reverse transcriptase and processed accordingly (Reverse Transcription System Kit; Promega). Selected negative control samples were prepared by including all reagents as above, minus the reverse transcriptase. A mastermix of RT reagents was prepared once to minimise potential variation.

All primer sequences in this study were obtained from published references (Fenwick et al. 2008a, 2008b, Anstaett et al. 2010). For each gene, PCR conditions were optimised by conventional PCR amplification using Platinum PCR Supermix containing Taq polymerase (Invitrogen; Invitrogen Ltd) and the addition of 50-75 ng DNase-treated RT RNA and primers $(20 \mathrm{mM})$; the presence of a single product was confirmed by electrophoresis on a $2 \%(\mathrm{w} / \mathrm{v})$ agarose gel. Once optimised, external standards were prepared from cDNAs identical to realtime PCR products and purified using QIAquick PCR purification columns (Qiagen). The identity of the cDNA products was confirmed by DNA sequence analysis (Geneservice Ltd, Cambridge, UK) and the precise concentration of purified cDNA product was determined using the NanoDrop ND-1000 spectrophotometer. Eight standards of a tenfold dilution of purified PCR product of each gene ranging between 10 and $1 \times 10^{-6} \mathrm{ng} / \mathrm{ml}$ (except RN18S1 for which the range was from 100 to $1 \times 10^{-5} \mathrm{ng} / \mathrm{ml}$ ) were diluted in nuclease-free water and included in each assay.

The cDNA concentration of IGF1, IGF2, IGFBP2, IGFBP3 and IGFBP6 was determined by a qPCR procedure with a singleplex SYBR Green I assay. ACTB and RN18S1 were tested as reference genes. To minimise variation, all cDNA samples included in each analysis were derived from the same batch. The mastermix was prepared once for each assay in order to avoid pipetting error. The amplification mixes contained $10 \mu \mathrm{l}$ KAPA SYBR FAST qPCR Kits (GRI, Braintree, Essex, UK), $0.5 \mu \mathrm{l}$ of $20 \mu \mathrm{M}$ forward and reverse primers mix, $4.5 \mu$ nuclease-free water and $5 \mu$ unknown sample (50 ng RT RNA). The qPCRs for both standards and samples were run in duplicate in closed white tubes. No template control (NTC) with nuclease-free water was included in every assay. Absolute concentrations of the PCR product were calculated by comparing the $C_{\mathrm{T}}$ values of the unknown samples to the standard curve using the CFX Manager Software Version 1.0.1035.131 (Bio-Rad Laboratories, Inc.). 
The expression was estimated as fg cDNA/50 ng RNA. The optimal annealing temperature, the plate reading temperature, the $R^{2}$ values relating to the standard curves and the efficiency of the assay for each gene are shown in Supplementary Table 1, see section on supplementary data given at the end of this article.

\section{Statistical analysis}

Statistical analysis of the data was carried out using SPSS 16.0 for Windows (Chicago, IL, USA). Data were tested for homogeneity of variance using a Levene's test and log transformation was performed if necessary. The data on both heifers and cows were initially analysed by paired $t$-test to compare the transcript number between the ipsilateral oviduct (adjacent to the dominant follicle) and the contralateral oviduct. A linear mixed effect model was then used for analysis. This model included time frame (day 14 luteal phase, pre-LH surge and post-LH surge), cow status (heifer or cow) and their interactions as the fixed effects and animal as the random effect. Data are presented as sample mean \pm s.E.M. Statistical significance was considered at a $P$ value of 0.05 .

\section{Supplementary data}

This is linked to the online version of the paper at http://dx.doi. org/10.1530/REP-11-0154.

\section{Declaration of interest}

The authors declare that there is no conflict of interest that could be perceived as prejudicing the impartiality of the research reported.

\section{Funding}

This work was supported by the Royal Thai Government and Science Foundation Ireland (07/SRC/B1156).

\section{Acknowledgements}

We thank F Carter and P Duffy for assistance with the animal work and P Furney for assistance with hormone assays.

\section{References}

Anstaett OL, Brownlie J, Collins ME \& Thomas CJ 2010 Validation of endogenous reference genes for RT-qPCR normalisation in bovine lymphoid cells (BL-3) infected with bovine viral diarrhoea virus (BVDV). Veterinary Immunology and Immunopathology 137 201-207. (doi:10.1016/j.vetimm.2010.05.006)

Bach LA 2005 IGFBP-6 five years on; not so 'forgotten'? Growth Hormone and IGF Research 15 185-192. (doi:10.1016/j.ghir.2005.04.001)

Bauersachs S, Blum H, Mallok S, Wenigerkind H, Rief S, Prelle K \& Wolf E 2003 Regulation of ipsilateral and contralateral bovine oviduct epithelial cell function in the postovulation period: a transcriptomics approach. Biology of Reproduction 68 1170-1177. (doi:10.1095/biolreprod.102. 010660)

Beltman ME, Forde N, Furney P, Carter F, Roche JF, Lonergan P \& Crowe MA 2010 Characterisation of endometrial gene expression and metabolic parameters in beef heifers yielding viable or non-viable embryos on day 7 after insemination. Reproduction, Fertility, and Development 22 987-999. (doi:10.1071/RD09302)

Bender K, Walsh S, Evans ACO, Fair T \& Brennan L 2010 Metabolite concentrations in follicular fluid may explain differences in fertility between heifers and lactating cows. Reproduction 139 1047-1055. (doi:10.1530/REP-10-0068)

Boilard M, Reyes-Moreno C, Lachance C, Massicotte L, Bailey JL, Sirard MA \& Leclerc P 2004 Localization of the chaperone proteins GRP78 and HSP60 on the luminal surface of bovine oviduct epithelial cells and their association with spermatozoa. Biology of Reproduction 71 1879-1889. (doi:10.1095/biolreprod.103.026849)

Brickell JS, Bourne N, McGowan MM \& Wathes DC 2009 Effect of growth and development during the rearing period on the subsequent fertility of nulliparous Holstein-Friesian heifers. Theriogenology 72 408-416. (doi:10.1016/j.theriogenology.2009.03.015)

Buhi WC 2002 Characterization and biological roles of oviduct-specific, oestrogen-dependent glycoprotein. Reproduction 123 355-362. (doi:10. 1530/rep.0.1230355)

Buhi WC, Alvarez IM \& Kouba AJ 2000 Secreted proteins of the oviduct. Cells, Tissues, Organs 166 165-179. (doi:10.1159/000016731)

Butler WR 2003 Energy balance relationships with follicular development, ovulation and fertility in postpartum dairy cows. Livestock Production Science 83 211-218. (doi:10.1016/S0301-6226(03)00112-X)

Christians JK \& Gruslin A 2010 Altered levels of insulin-like growth factor binding protein proteases in preeclampsia and intrauterine growth restriction. Prenatal Diagnosis 30 815-820. (doi:10.1002/pd.2583)

Clemmons DR 1997 Insulin-like growth factor binding proteins and their role in controlling IGF actions. Cytokine \& Growth Factor Reviews 8 45-62. (doi:10.1016/S1359-6101(96)00053-6)

Diskin MG \& Morris DG 2008 Embryonic and early foetal losses in cattle and other ruminants. Reproduction in Domestic Animals 43 (Supplement 2) 260-267. (doi:10.1111/j.1439-0531.2008.01171.x)

Ellington JE 1991 The bovine oviduct and its role in reproduction: a review of the literature. Cornell Veterinarian 81 313-328.

Fenwick MA, Fitzpatrick R, Kenny DA, Diskin MG, Patton J, Murphy JJ \& Wathes DC 2008a Interrelationships between negative energy balance (NEB) and IGF regulation in liver of lactating dairy cows. Domestic Animal Endocrinology 34 31-44. (doi:10.1016/j.domaniend.2006.10.002)

Fenwick MA, Llewellyn S, Fitzpatrick R, Kenny DA, Murphy JJ, Patton J \& Wathes DC $2008 b$ Negative energy balance in dairy cows is associated with specific changes in IGF-binding protein expression in the oviduct. Reproduction 135 63-75. (doi:10.1530/REP-07-0243)

Forde N, Beltman ME, Duffy GB, Duffy P, Mehta JP, Ó'Gaora P, Roche JF, Lonergan $\mathbf{P} \&$ Crowe MA 2010 Changes in the endometrial transcriptome during the bovine estrous cycle: effect of low circulating progesterone and consequences for conceptus elongation. Biology of Reproduction 84 266-278. (doi:10.1095/biolreprod.110.085910)

Gadd TS, Osgerby JC \& Wathes DC 2002 Regulation of insulin-like growth factor binding protein- 6 expression in the reproductive tract throughout the estrous cycle and during the development of the placenta in the ewe. Biology of Reproduction 67 1756-1762. (doi:10.1095/biolreprod67.6. 1756)

Geisert RD, Lee CY, Simmen FA, Zavy MT, Fliss AE, Bazer FW \& Simmen RC 1991 Expression of messenger RNAs encoding insulin-like growth factor-I, -II, and insulin-like growth factor binding protein-2 in bovine endometrium during the estrous cycle and early pregnancy. Biology of Reproduction 45 975-983. (doi:10.1095/biolreprod45.6.975)

Henricks DM, Kouba AJ, Lackey BR, Boone WR \& Gray SL 1998 Identification of insulin-like growth factor I in bovine seminal plasma and its receptor on spermatozoa: influence on sperm motility. Biology of Reproduction 59 330-337. (doi:10.1095/biolreprod59.2.330)

Hunter RHF 1988 The Fallopian Tubes: Their Role in Fertility and Infertility, Berlin: Springer-Verlag.

Jones JI \& Clemmons DR 1995 Insulin-like growth factors and their binding proteins: biological actions. Endocrine Reviews 16 3-34. (doi:10.1210/ edrv-16-1-3)

Kuhn MT, Hutchison JL \& Wiggans GR 2006 Characterization of Holstein heifer fertility in the United States. Journal of Dairy Science 89 4907-4920. (doi:10.3168/jds.S0022-0302(06)72541-3)

Lai YM, Wang HS, Lee CL, Lee JD, Huang HY, Chang FH, Lee JF \& Soong YK 1996 Insulin-like growth factor-binding proteins produced by Vero cells, 
human oviductal cells and human endometrial cells, and the role of insulin-like growth factor-binding protein-3 in mouse embryo co-culture systems. Human Reproduction 11 1281-1286.

Leese HJ 1988 The formation and function of oviduct fluid. Journal of Reproduction and Fertility 82 843-856. (doi:10.1530/jrf.0.0820843)

Leese HJ, Baumann CG, Brison DR, McEvoy TG \& Sturmey RG 2008 Metabolism of the viable mammalian embryo: quietness revisited. Molecular Human Reproduction 14 667-672. (doi:10.1093/molehr/ gan065)

LeRoith D, Werner H, Neuenschwander S, Kalebic T \& Helman LJ 1995 The role of the insulin-like growth factor-I receptor in cancer. Annals of the New York Academy of Sciences 766 402-408. (doi:10.1111/j.17496632.1995.tb26689.x)

Leroy JL, Vanholder T, Van Knegsel AT, Garcia-Ispierto I \& Bols PE 2008 Nutrient prioritization in dairy cows early postpartum: mismatch between metabolism and fertility? Reproduction in Domestic Animals 43 (Supplement 2) 96-103. (doi:10.1111/j.1439-0531.2008.01148.x)

Llewellyn S, Fitzpatrick R, Kenny DA, Murphy J, Scaramuzzi RJ \& Wathes DC 2007 Effect of negative energy balance on the insulin-like growth factor system in pre-recruitment ovarian follicles of post partum dairy cows. Reproduction 133 627-639. (doi:10.1530/REP-06-0122)

Lucy MC 2001 Reproductive loss in high-producing dairy cattle: where will it end? Journal of Dairy Science 84 1277-1293. (doi:10.3168/jds.S00220302(01)70158-0)

Lucy MC, Jiang H \& Kobayashi Y 2001 Changes in the somatotrophic axis associated with the initiation of lactation. Journal of Dairy Science $\mathbf{8 4}$ E113-E119. (doi:10.3168/jds.S0022-0302(01)70205-6)

Matsui M, Takahashi Y, Hishinuma M \& Kanagawa H 1997 Stimulation of the development of bovine embryos by insulin and insulin-like growth factor-I (IGF1) is mediated through the IGF1 receptor. Theriogenology $\mathbf{4 8}$ 605-616. (doi:10.1016/S0093-691X(97)00277-X)

Mihm M \& Evans AC 2008 Mechanisms for dominant follicle selection in monovulatory species: a comparison of morphological, endocrine and intraovarian events in cows, mares and women. Reproduction in Domestic Animals 43 (Supplement 2) 48-56. (doi:10.1111/j.14390531.2008.01142.x)

Moore K, Kramer JM, Rodriguez-Sallaberry CJ, Yelich JV \& Drost M 2007 Insulin-like growth factor (IGF) family genes are aberrantly expressed in bovine conceptuses produced in vitro or by nuclear transfer. Theriogenology 68 717-727. (doi:10.1016/j.theriogenology.2007.06.001)

Murray MK 1995 Epithelial lining of the sheep ampulla oviduct undergoes pregnancy-associated morphological changes in secretory status and cell height. Biology of Reproduction 53 653-663. (doi:10.1095/biolreprod53.3.653)

Nayak RK, Albert EN \& Kassira WN 1976 Cyclic ultrastructural changes in ewe uterine tube (oviduct) infundibular epithelium. American Journal of Veterinary Research 37 923-933.

Neira JA, Tainturier D, Pena MA \& Martal J 2010 Effect of the association of IGF1, IGF2, bFGF, TGF-beta1, GM-CSF, and LIF on the development of bovine embryos produced in vitro. Theriogenology 73 595-604. (doi:10. 1016/j.theriogenology.2009.10.015)

Palma GA, Müller M \& Brem G 1997 Effect of insulin-like growth factor I (IGF-I) at high concentrations on blastocyst development of bovine embryos produced in vitro. Journal of Reproduction and Fertility 110 347-353. (doi:10.1530/jrf.0.1100347)

Patton J, Kenny DA, McNamara S, Mee JF, O'Mara FP, Diskin MG \& Murphy JJ 2007 Relationships among milk production, energy balance, plasma analytes, and reproduction in Holstein-Friesian cows. Journal of Dairy Science 90 649-658. (doi:10.3168/jds.S0022-0302(07)71547-3)

Pershing RA, Lucy MC, Thatcher WW \& Badinga L 2002 Effects of BST on oviductal and uterine genes encoding components of the IGF system in lactating dairy cows. Journal of Dairy Science 85 3260-3267. (doi:10. 3168/jds.S0022-0302(02)74414-7)

Pushpakumara PG, Robinson RS, Demmers KJ, Mann GE, Sinclair KD, Webb R \& Wathes DC 2002 Expression of the insulin-like growth factor (IGF) system in the bovine oviduct at oestrus and during early pregnancy. Reproduction 123 859-868. (doi:10.1530/rep.0.1230859)

Rajaram S, Baylink DJ \& Mohan S 1997 Insulin-like growth factor-binding proteins in serum and other biological fluids: regulation and functions. Endocrine Reviews 18 801-831. (doi:10.1210/er.18.6.801)

Robinson RS, Hammond AJ, Wathes DC, Hunter MG \& Mann GE 2008 Corpus luteum-endometrium-embryo interactions in the dairy cow: underlying mechanisms and clinical relevance. Reproduction in Domestic Animals 43 (Supplement 2) 104-112. (doi:10.1111/j.14390531.2008.01149.x)

Rodriguez-Martinez H 2007 Role of the oviduct in sperm capacitation. Theriogenology 68 (Supplement 1) S138-S146. (doi:10.1016/j.theriogenology.2007.03.018)

Santos JE, Thatcher WW, Chebel RC, Cerri RL \& Galvao KN 2004 The effect of embryonic death rates in cattle on the efficacy of estrus synchronization programs. Animal Reproduction Science 82-83 513-535. (doi:10. 1016/j.anireprosci.2004.04.015)

Schmidt A, Einspanier R, Amselgruber W, Sinowatz F \& Schams D 1994 Expression of insulin-like growth factor 1 (IGF-1) in the bovine oviduct during the oestrous cycle. Experimental and Clinical Endocrinology 102 364-369. (doi:10.1055/s-0029-1211305)

Simmen RC, Simmen FA, Hofig A, Farmer SJ \& Bazer FW 1990 Hormonal regulation of insulin-like growth factor gene expression in pig uterus. Endocrinology 127 2166-2174. (doi:10.1210/endo-127-52166)

Stevenson KR \& Wathes DC 1996 Insulin-like growth factors and their binding proteins in the ovine oviduct during the oestrous cycle. Journal of Reproduction and Fertility 108 31-40. (doi:10.1530/jrf.0. 1080031)

Taylor VJ, Cheng Z, Pushpakumara PG, Beever DE \& Wathes DC 2004 Relationships between the plasma concentrations of insulin-like growth factor-I in dairy cows and their fertility and milk yield. Veterinary Record 155 583-588. (doi:10.1136/vr.155.19.583)

Thissen JP, Ketelslegers JM \& Underwood LE 1994 Nutritional regulation of the insulin-like growth factors. Endocrine Reviews 15 80-101. (doi:10. 1210/edrv-15-1-80)

Tiemann U \& Hansen PJ 1995 Steroidal and growth factor regulation of $\left[{ }^{3} \mathrm{H}\right]$ thymidine incorporation by cultured endosalpingeal cells of the bovine oviduct. In Vitro Cellular \& Developmental Biology. Animal 31 640-645. (doi:10.1007/BF02634318)

Ullrich A, Gray A, Tam AW, Yang-Feng T, Tsubokawa M, Collins C, Henzel W, Le Bon T, Kathuria S, Chen E et al. 1986 Insulin-like growth factor I receptor primary structure: comparison with insulin receptor suggests structural determinants that define functional specificity. $E M B O$ Journal 5 2503-2512.

Veerkamp RF, Koenen EP \& De Jong G 2001 Genetic correlations among body condition score, yield, and fertility in first-parity cows estimated by random regression models. Journal of Dairy Science 84 2327-2335. (doi:10.3168/jds.S0022-0302(01)74681-4)

Velazquez MA, Spicer LJ \& Wathes DC 2008 The role of endocrine insulinlike growth factor-I (IGF1) in female bovine reproduction. Domestic Animal Endocrinology 35 325-342. (doi:10.1016/j.domaniend.2008.07. 002)

Wang LM, Feng HL, Ma Y, Cang M, Li HJ, Yan Z, Zhou P, Wen JX, Bou S \& Liu DJ 2009 Expression of IGF receptors and its ligands in bovine oocytes and preimplantation embryos. Animal Reproduction Science 114 99-108. (doi:10.1016/j.anireprosci.2008.09.019)

Warzych E, Wrenzycki C, Peippo J \& Lechniak D 2007 Maturation medium supplements affect transcript level of apoptosis and cell survival related genes in bovine blastocysts produced in vitro. Molecular Reproduction and Development 74 280-289. (doi:10.1002/ mrd.20610)

Wathes DC, Reynolds TS, Robinson RS \& Stevenson KR 1998 Role of the insulin-like growth factor system in uterine function and placental development in ruminants. Journal of Dairy Science 81 1778-1789. (doi:10.3168/jds.S0022-0302(98)75747-9)

Wathes DC, Fenwick M, Cheng Z, Bourne N, Llewellyn S, Morris DG, Kenny D, Murphy J \& Fitzpatrick R 2007a Influence of negative energy balance on cyclicity and fertility in the high producing dairy cow. Theriogenology 68 (Supplement 1) S232-S241. (doi:10.1016/j.theriogenology.2007.04.006)

Wathes DC, Cheng Z, Bourne N, Taylor VJ, Coffey MP \& Brotherstone S $2007 b$ Differences between primiparous and multiparous dairy cows in the inter-relationships between metabolic traits, milk yield and body condition score in the periparturient period. Domestic Animal Endocrinology 33 203-225. (doi:10.1016/j.domaniend.2006.05.004)

Wathes DC, Cheng Z, Chowdhury W, Fenwick MA, Fitzpatrick R, Morris DG, Patton J \& Murphy JJ 2009a Negative energy balance alters 
global gene expression and immune responses in the uterus of postpartum dairy cows. Physiological Genomics 39 1-13. (doi:10. 1152/physiolgenomics.00064.2009)

Wathes DC, Clempson AM \& Brickell JS 2009b Environmental and genetic influences on successful heifer rearing. In Recent Advances in Animal Nutrition, pp 21-48. Eds PC Garnsworthy \& J Wiseman. Nottingham: Nottingham University Press.

Wathes DC, Cheng Z, Fenwick MA, Fitzpatrick R \& Patton J 2011 Influence of energy balance on the somatotrophic axis and matrix metalloproteinase expression in the endometrium of the postpartum dairy cow. Reproduction 141 269-281. (doi:10.1530/REP-10-0177)

Watson AJ, Westhusin ME \& Winger QA 1999 IGF paracrine and autocrine interactions between conceptus and oviduct. Journal of Reproduction and Fertility Supplement $\mathbf{5 4}$ 303-315.

Winger QA, de los Rios P, Han VK, Armstrong DT, Hill DJ \& Watson AJ 1997 Bovine oviductal and embryonic insulin-like growth factor binding proteins: possible regulators of "embryotrophic" insulin-like growth factor circuits. Biology of Reproduction 56 1415-1423. (doi:10.1095/ biolreprod56.6.1415)

Woelfle J \& Rotwein P 2004 In vivo regulation of growth hormonestimulated gene transcription by STAT5b. American Journal of Physiology. Endocrinology and Metabolism 286 E393-E401. (doi:10. 1152/ajpendo.00389.2003)
Xia P, Han VK, Viuff D, Armstrong DT \& Watson AJ 1996 Expression of insulin-like growth factors in two bovine oviductal cultures employed for embryo co-culture. Journal of Endocrinology 149 41-53. (doi:10.1677/ joe.0.1490041)

Yaniz JL, Lopez-Gatius F, Santolaria P \& Mullins KJ 2000 Study of the functional anatomy of bovine oviductal mucosa. Anatomical Record $\mathbf{2 6 0}$ 268-278. (doi:10.1002/1097-0185(20001101)260:3 <268::AID-AR60> 3.0.CO; $2-\mathrm{L})$

Yaseen MA, Wrenzycki C, Herrmann D, Carnwath JW \& Niemann H 2001 Changes in the relative abundance of mRNA transcripts for insulin-like growth factor (IGF1 and IGF2) ligands and their receptors (IGF1R/IGF2R) in preimplantation bovine embryos derived from different in vitro systems. Reproduction 122 601-610. (doi:10.1530/rep.0.1220601)

Yding Andersen C 2002 Possible new mechanism of cortisol action in female reproductive organs: physiological implications of the free hormone hypothesis. Journal of Endocrinology 173 211-217. (doi:10. 1677/joe.0.1730211)

Received 5 May 2011

First decision 2 June 2011

Accepted 5 July 2011 